\title{
Uranium Resources of
}

the San Rafael District

Emery County, Utah-

a Regional Synthesis

GEOLOGICAL SURVEY BULLETIN 1046 -D

This report concerns work done on behalf of the U.S. Atomic Energy Commission and is published with the permission of the Commission 


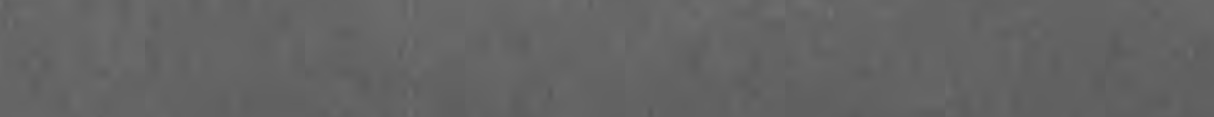

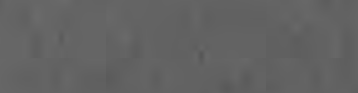

fing

$$
\text { Gir }
$$

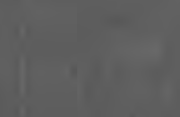

$$
\begin{aligned}
& -\ln ^{2} \mathrm{~m}^{2}
\end{aligned}
$$

4.

क.

$x^{2} x^{2}+x^{2}=$

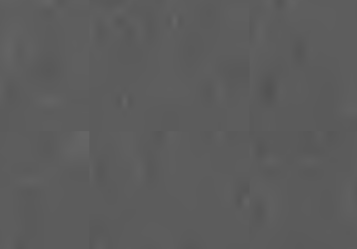

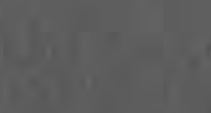

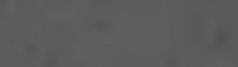

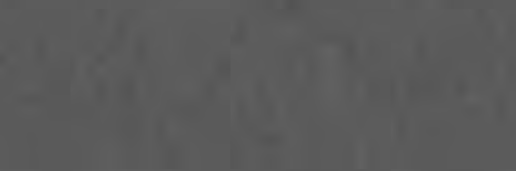

(1)

1.

4

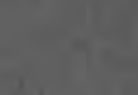

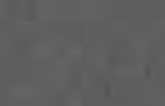

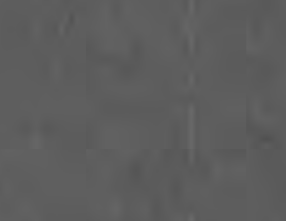

14 $-1$

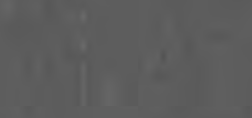

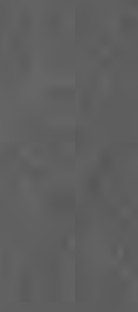

,

II

$-5$

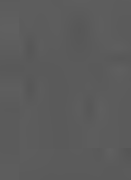

$16=$

$a_{4}=-2=$

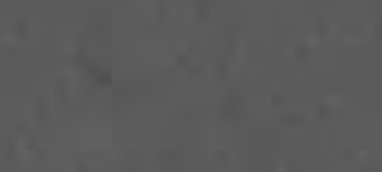

4

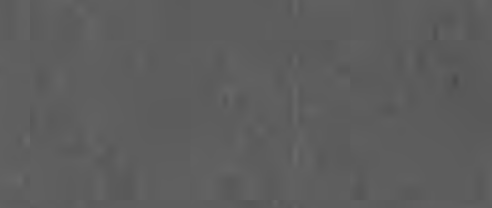

int

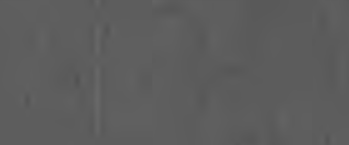

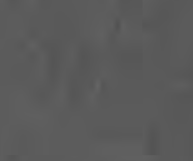

이

ind

(a)

$4=1$, $x^{2}$

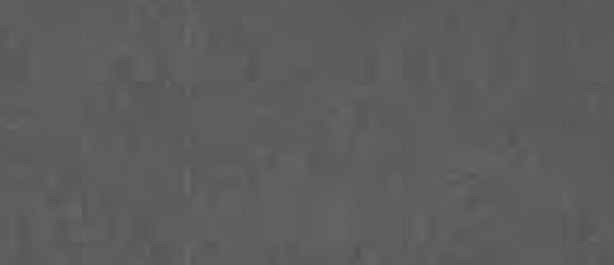

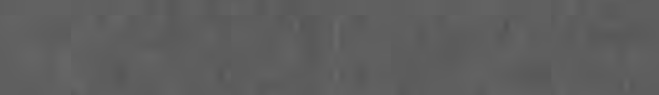

$\frac{14}{2+3}$

(25)

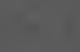

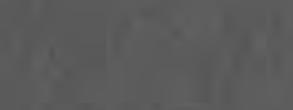




\section{ERRATA}

Bulletin 1046-D, Uranium resources of the San Rafael district, Emery County, Utah, by H. S. Johnson, plate 2.

The explanation beneath the first and third boxes has been transposed. The correct explanation is as follows:

\section{EXPLANATION}

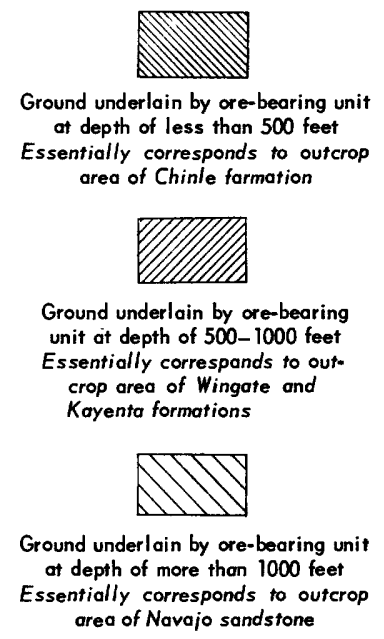





\section{Uranium Resources of}

the San Rafael District

Emery County, Utah-

a Regional Synthesis

By H. S. JOHNSON, Jr.

CONTRIBUTIONS TO THE GEOLOGY OF URANIUM

G E O L O G I C A L S U R V E Y B U L L E T I N $1046-\mathrm{D}$

This report concerns work done on behalf of the U.S. Atomic Energy Commission and is published with the permission of the Commission

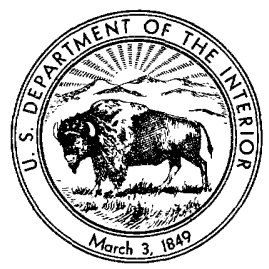




\title{
UNITED STATES DEPARTMENT OF THE INTERIOR
}

FRED A. SEATON, Secretary

\author{
GEOLOGICAL SURVEY
}

Thomas B. Nolan, Director 


\section{CONTENTS}

\begin{tabular}{|c|c|}
\hline & Page \\
\hline Abstract. & 37 \\
\hline 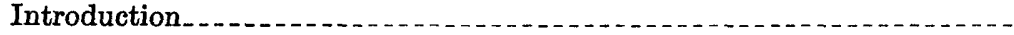 & 37 \\
\hline Purpose of report & 37 \\
\hline Sources of data and methods of study & 38 \\
\hline Geography & 39 \\
\hline History of mining & 39 \\
\hline Geology & 41 \\
\hline Stratigraphy & 41 \\
\hline Chinle formation & 41 \\
\hline Temple Mountain member & 42 \\
\hline Monitor Butte member & 43 \\
\hline Moss Back member & 43 \\
\hline Church Rock member & 44 \\
\hline "Purple-white" zone & 44 \\
\hline Bleaching of the Moenkopi formation & 45 \\
\hline Structure & 45 \\
\hline Igneous rockss & 46 \\
\hline Ore deposits & 46 \\
\hline Relative favorability of ground. & 50 \\
\hline Summary & 52 \\
\hline Literature cited & 53 \\
\hline
\end{tabular}

\section{ILLUSTRATIONS}

Prate 2. Map of San Rafael district, Emery County, Utah, showing uranium deposits and ground underlain by the ore-bearing unit. In pocket

Figure 12. Index map of part of Utah showing location of the San Rafael district and adjacent districts.

13. Bar graph showing percentage of the total amount of ore (total production through 1954 plus indicated and inferred reserves) in the San Rafael district that is contained in deposits of various size ranges. 



\title{
CONTRIBUTIONS TO THE GEOLOGY OF URANIUM
}

\section{URANIUM RESOURGES OF THE SAN RAFAEL DISTRICT, EMERY COUNTY, UTAH-A REGIONAL SYNTHESIS}

\author{
By H. S. Johnson, JR.
}

\section{ABSTRACT}

Uranium occurs with minor amounts of copper and vanadium in sandstones in the Chinle formation in the San Rafael district, Emery County, Utah. Reconnaissance visits to ore deposits and study of available data suggest that about 90 percent of the potential reserves of the area may be expected to occur in deposits larger than 100,000 tons in size. Assuming that there is no tectonic structural control of the ore deposits, about 40 percent of the potential reserves may be expected at depths of less than 1,000 feet.

The thin blanketlike Temple Mountain member of the Chinle formation overlies the Moenkopi formation over most of the San Rafael district and is considered relatively unfavorable for significant uranium deposits.

The Monitor Butte member of the Chinle formation is about 100 feet in thickness in the vicinity of the Delta mine in the south end of the San Rafael Swell and pinches out just south of Temple Mountain and Green Vein Mesa. This unit is considered relatively favorable for large uranium deposits wherever it contains sandstone lenses approaching the thickness (10 to 30 feet or more) of the lens at the Delta mine.

The Moss Back member of the Chinle formation is considered relatively favorable for significant uranium deposits along the southeastward or northwestward trend of a favorable belt passing through Temple Mountain and Green Vein Mesa and wherever it contains channels in that part of the San Rafael Swell south of Temple Mountain and Green Vein Mesa.

\section{INTRODUCTION PURPOSE OF REPORT}

The purpose of this report is to present the preliminary results of geologic reconnaissance and office study leading to an appraisal of the geologic relations of the uranium deposits of the San Rafael district, Emery County, Utah (fig. 12). The report is part of a series of similar reports synthesizing the geologic relations of uranium deposits in all formations on the Colorado Plateau. The history, general geology, and uranium occurrences of the San Rafael district are briefly reviewed; and an attempt is made to appraise the relative favorability of potentially ore-bearing geologic formations for significant uranium 


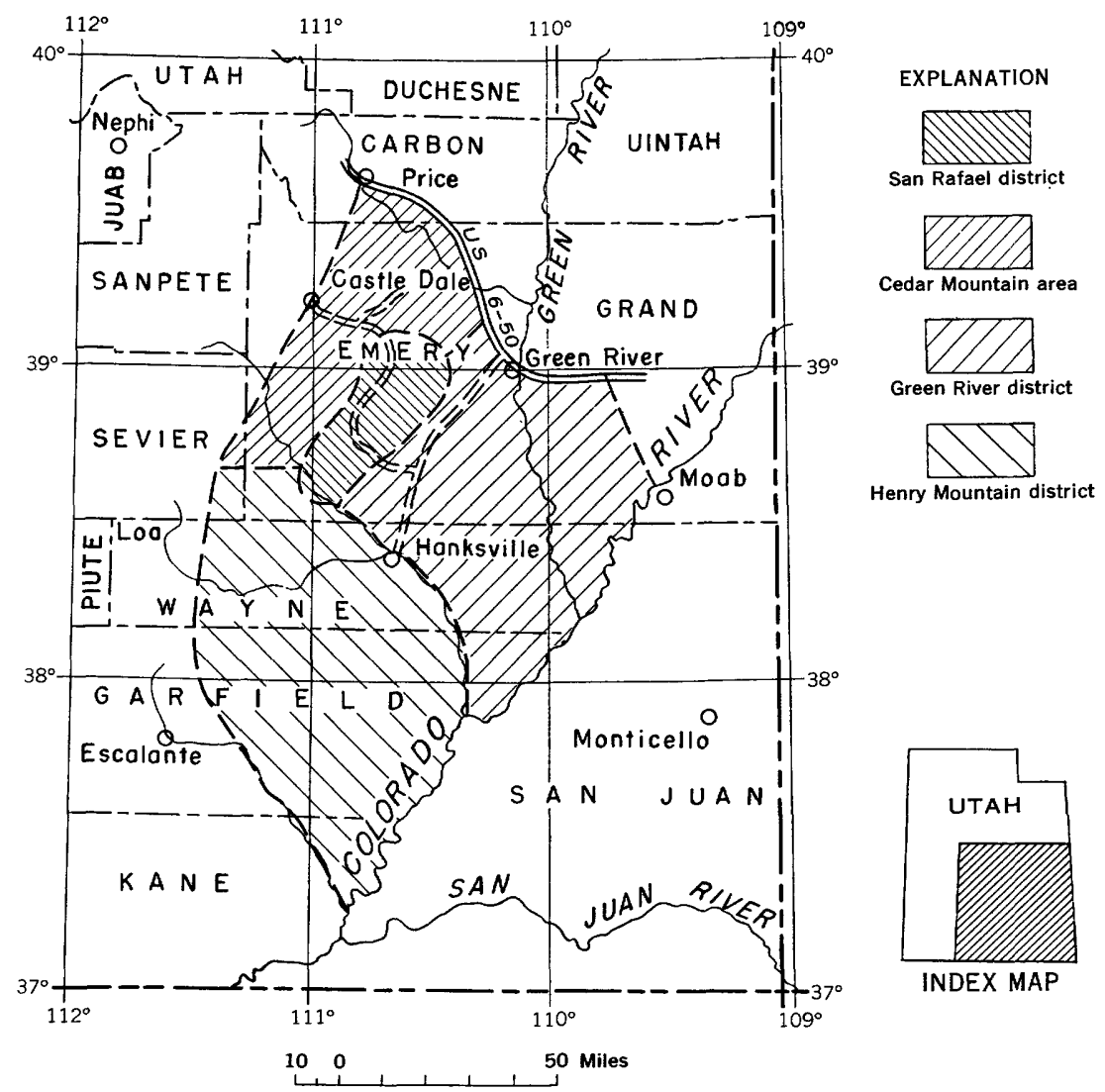

Froure 12.-Index map of part of Utah showing location of the San Rafael district and adjacent districts.

deposits. Expected deposit size, depth to ore, ore controls, and major controls of favorable ground are also discussed.

Field work was carried on during the summers of 1954 and 1955 as part of regional reconnaissance studies of uranium resources of all geologic formations on the Colorado Plateau and was done by the U. S. Geological Survey on behalf of the Division of Raw Materials of the U. S. Atomic Energy Commission.

\section{SOURCES OF DATA AND METHODS OF STUDY}

Data used in this study include production records maintained by the Grand Junction Operations Office of the U. S. Atomic Energy Commission, reserve estimates made by the Commission as a result of exploratory drilling, reserve estimates and geologic observations made by the writer, and data contained in U. S. Atomic Energy Commission and U. S. Geological Survey published and unpublished reports. 
Field work consisted of reconnaissance visits to most of the known uranium deposits in the district. At each deposit an attempt was made to determine the stratigraphic position of the ore-bearing unit; lithologic, stratigraphic, and structural controls affecting deposition of the ore; ore and (or) channel trends; indicated and inferred reserves; and potential reserves in the deposit area.

Office work consisted principally of compilation and synthesis of available data. Special thanks are due R. C. Robeck of the Geological Survey for making available some of the preliminary results of detailed mapping done by him in the San Rafael Swell during 1954 and 1955.

\section{GEOGRAPHY}

The San Rafael district is in Emery County, Utah. In this report the name refers to the area within the continuous line of outcrop of the contact between the Navajo sandstone and the Carmel formation around the flanks of the San Rafael Swell domal structure. The area essentially corresponds to the topographic expression of the San Rafael Swell and is an elongate north-northeastward trending oval about 50 miles long by 20 miles wide. Access is provided by 40 miles of graded dirt and gravel road leading southwest from U. S. Highway 50 at a point 4 miles west of Green River, Utah (fig. 12). A similar road leaves U. S. Highway 50 about 22 miles west of Green River and skirts the north end of the San Rafael Swell to enter the district by way of Buckhorn Wash.

The San Rafael Swell is bounded on all sides by the cliff (or "reef," as it is called locally) formed by thick massive sandstone beds of the Wingate, Kayenta, and Navajo formations exposed on the flanks of the domal structure. On the ends and flanks of the structure the land surface is rather sharply dissected so that it consists largely of remnants of mesas and steep-walled canyons or cliff-like slopes. Erosion has exposed the central part as a broad, open, gently domed area that is in most places higher than the surrounding reef, even though this reef may stand 1,500 feet or more above the area immediately adjacent to it. Two perennial streams, the San Rafael and Muddy Rivers, flow southeastward across the north and south ends of the dome, respectively, and most of the intermittent drainage from the rest of the San Rafael Swell eventually reaches one of these streams. The climate is semiarid with very hot summers and cold winters. Water and fuel have to be brought considerable distances to most of the San Rafael Swell, and labor and mining supplies are obtainable no closer than the town of Green River.

\section{HISTORY OF MINING}

Uranium ores in what is now known as the San Rafael district were first reported by Hess and Schaller (1914). These were the Temple 
Mountain deposits on the east flank of the San Rafael Swell (pl. 2) and were associated with asphaltic material in sandstone. In 1916, Moore and Kithil (1916) reported ". . . deposits of red calcium vanadate, and carnotite in beds of sandstone several feet thick carrying both uranium and vanadium ..." at "Table Mountain" (presumably Temple Mountain), 45 miles south of the town of Green River. Two years later Emery (1918) stated that "In the Temple Mountain region, it (the Shinarump [sic]) is the source of the radiumbearing ores which occur in pockets associated with fossil wood."

The Temple Mountain deposits were mined for radium and possibly byproduct vanadium during the period of World War I. Hess (1922) wrote that "A considerable tonnage of ore shipped during the war averaged about 1.75 percent $\mathrm{U}_{3} \mathrm{O}_{8}$ and 4 percent $\mathrm{V}_{2} \mathrm{O}_{5}$. . ." R. M. Murphy (written communication, 1944) reported that "There is much conflict in the many more or less indefinite accounts of the extent of production from these workings and the gross value of the output is entirely unknown. The deposit has been exploited intermittently from about the year 1918 to 1942. In the latter year some ore, variously reported to have totaled from 150 tons to 15 cars, was shipped." Prior to 1948 no ore was mined from other parts of the San Rafael district.

Union Mines Development Corp. geologists studied the Temple Mountain area for the Manhattan Engineer District during World War II and concluded that very large tonnages of low-grade ore were present (R. M. Murphy, written communication, 1944). After the war, production from the Temple Mountain deposits began to increase rapidly. When attention focused on Temple Mountain, prospectors were attracted to the San Rafael Swell and quickly discovered other deposits.

In 1948, Temple Mountain was the only producing area in the San Rafael district. The next year there was small production from three deposits other than those in Temple Mountain proper. In 1950 and 1951, Temple Mountain was the major producer in the area with small shipments being made from about 10 other deposits. In 1951, the Lucky Strike mine came into production on a limited scale; and in 1952, Vernon Pick's Delta mine joined the list of producing mines. From 1952 to 1956, production has come from 2 big mines (the Temple Mountain deposits and the Delta mine), 1 middle-sized mine (the Lucky Strike), and from 10 to 15 other deposits which make small shipments from time to time.

A number of reports containing the results of geologic investigations in the San Rafael district have been published (see Literature cited). Also, data (all from written communications) from geologic investigations by R. M. Murphy, 1944; C. W. Chesterman and F. H. Main, 
1947; W. L. Stokes, 1947 ; M. J. Sheridan, 1951; G. L. Brooke, 1952; A. H. Anderson and R. D. Miller, 1952 ; R. C. Gerhard, 1953; D. G. Wyant, 1953; and I. J. Witkind and others, 1954; have contributed to the understanding of the geology of this area. Geologic mapping of the ore-bearing formations by members of the Geological Survey is now in progress. For several years the U. S. A tomic Energy Commission has been carrying on reconnaissance, exploration drilling, and detailed geologic studies in the San Rafael district.

\section{GEOLOGY}

\section{STRATIGRAPHY}

The rocks exposed within the boundaries of the San Rafael district range in age from Pennsylvanian to Jurassic and consist of limestone, shale, siltstone, sandstone, and conglomerate (see generalized section, p. 42). A series of limestones tentatively correlated with the Hermosa formation of Pennsylvanian age is reported by Baker (1946) to crop out in the canyon of Straight Wash in the eastern part of the San Rafael Swell. The Coconino sandstone and overlying Kaibab limestone of Permian age crop out in many of the deep canyons in the central parts of the San Rafael Swell. Elsewhere in the central parts the surface is formed by the Moenkopi formation of Triassic age. This Moenkopi consists predominantly of alternating evenly bedded siltstone and fine-grained sandstone, and the sandy Sinbad limestone member forms part of the lower half of the formation. The Chinle, Wingate, Kayenta, and Navajo formations of Triassic and Jurassic age overlie the Moenkopi and form benches and steep slopes and cliffs around the flanks of the domal structure. As uranium deposits in the San Rafael district are essentially confined to the Chinle formation, this unit was observed more closely than other formations during reconnaissance visits to the district.

\section{CHINLE FORMATION}

The Chinle formation overlies the Moenkopi in the San Rafael district and may be divided into four members. The basal member has recently been defined and named by Robeck (1956) as the Temple Mountain member. Above this, in ascending order, are three members thought to correlate with the Monitor Butte member, recognized and described by I. J. Witkind (written communication) in Monument Valley, Ariz.; the Moss Back member, recognized and described by Stewart (1957) in White Canyon, Utah; and the Church Rock member, also recognized by Witkind in Monument Valley, Ariz. In earlier reports (Gilluly and Reeside, 1928; and Gilluly, 1929), the members now identified as the Temple Mountain, Monitor Butte, and Moss Back were included in the Shinarump conglomerate. 
Generalized section of rock formations in the San Rafael district, Emery County, Utah 1

\begin{tabular}{|c|c|c|c|c|c|c|}
\hline & System & Series & & $\begin{array}{l}\text { Group and } \\
\text { formation }\end{array}$ & $\begin{array}{l}\text { Thick- } \\
\text { ness } \\
\text { (feet) }\end{array}$ & Description \\
\hline & $\begin{array}{l}\text { Jurassic and } \\
\text { Jurassic (?) }\end{array}$ & & 옥 & $\begin{array}{l}\text { Navajo sand- } \\
\text { stone }\end{array}$ & $440-650$ & $\begin{array}{l}\text { Tan to light-gray massive } \\
\text { crossbedded sandistone, } \\
\text { with a few thin limestone } \\
\text { lenses. }\end{array}$ \\
\hline & Jurassic(?) & & 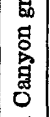 & $\begin{array}{l}\text { Kayenta for- } \\
\text { mation }\end{array}$ & $44-240$ & $\begin{array}{l}\text { Reddish-brown sandstone } \\
\text { and green and red silt- } \\
\text { stone; irregular interfin- } \\
\text { gering of sandstone and } \\
\text { siltstone. }\end{array}$ \\
\hline & & & $\frac{5}{0}$ & $\begin{array}{l}\text { Wingate sand. } \\
\text { stone }\end{array}$ & $360-400$ & $\begin{array}{l}\text { Buff to tan, dark-gray, and } \\
\text { light-pinkish-brown mas- } \\
\text { sive crossbedded sand- } \\
\text { stone, with a few thin } \\
\text { lenses of limestone. }\end{array}$ \\
\hline & Triassic & Upper Tri- & Chi & Inle formation & $220-440$ & $\begin{array}{l}\text { Reddish-brown sandstone, } \\
\text { reddish-brown siltstone, } \\
\text { and variegated red and } \\
\text { green calcareous mudstone; } \\
\text { conglomeratic sandstone; } \\
\text { limestone pebble conglom- } \\
\text { erate; purplish-red mud- } \\
\text { stone; greenish-gray, pur- } \\
\text { ple to reddish-brown mot- } \\
\text { tled siltstone and con- } \\
\text { glomeratic sandstone, high- } \\
\text { ly carbonaceous in places. }\end{array}$ \\
\hline & & $\begin{array}{l}\text { Unconformity } \\
\text { Lower and } \\
\text { Middle(?) } \\
\text { Triassic }\end{array}$ & Mo & $\begin{array}{l}\text { enkopi forma } \\
\text { ion }\end{array}$ & $600-800(?)$ & $\begin{array}{l}\text { Greenish-gray pyritic silt- } \\
\text { stone; gypsiferous green } \\
\text { and red siltstone; red mi- } \\
\text { caceous ripple-marked } \\
\text { sandstone and siltstone; } \\
\text { and Sinbad limestone } \\
\text { member. }\end{array}$ \\
\hline & Pormion & Unconformity & Kai & ibab limestone & $0-85$ & $\begin{array}{l}\text { Light-gray to brown cherty } \\
\text { and sandy limestone. }\end{array}$ \\
\hline & & & $\begin{array}{r}\text { Coc } \\
\text { st }\end{array}$ & one & $685 \pm$ & $\begin{array}{l}\text { Massive crossbedded light- } \\
\text { gray to buff medium- to } \\
\text { coarse-grained sandstone. }\end{array}$ \\
\hline 宊 & $\begin{array}{c}\text { Pennsyl- } \\
\text { vanian }\end{array}$ & & $\begin{array}{r}\text { Her } \\
\text { tic }\end{array}$ & $\begin{array}{l}\text { mosa forma- } \\
\text { on(?) }\end{array}$ & $432 \pm$ & $\begin{array}{l}\text { Interbedded gray to tan } \\
\text { sandstone and gray to pink } \\
\text { more or less cherty lime- } \\
\text { stone; exposed im Straight } \\
\text { Wash Canyon. }\end{array}$ \\
\hline
\end{tabular}

In part after Gilluly (1929) and Baker (1946).

\section{TEMPLE MOUNTAIN MEMBER}

The Temple Mountain member of the Chinle formation of Triassic age has been mapped by R. C. Robeck and H. B. Dyer (written communication) of the U. S. Geological Survey. This unit unconformably overlies the Moenkopi formation and seems to have been deposited as a thin blanket (as much as 100 feet thick but usually much thinner) of fluviatile shale, siltstone, and sandstone over most of the San Rafael Swell. Because of a distinctive purple, red, brown, and white mottled color phenomenon commonly associated with this unit but not always limited to it stratigraphically, the Temple Mountain member is sometimes referred to as the "purple-white" or "pinto" zone. Relief on the Moenkopi surface is low, and channels cut in this surface and filled by the Temple Mountain member are usually 
broad and shallow. In a few places the streams that deposited the Temple Mountain member cut deeper into the Moenkopi surface, where a maximum depth of $\mathbf{7 0}$ feet has been observed (Raymond C. Robeck, oral communication).

The Temple Mountain member of the Chinle in the San Rafael district consists of purple mudstone and siltstone with light-gray to light-brown sandstone lenses dispersed in irregular positions in the unit. Fine to coarse clear rounded to subangular quartz grains are scattered throughout most of the fine-grained clastic rocks. Channel-fill and nonchannel deposits appear to be the two principal types of deposits in the Temple Mountain member.

Channel-fill deposits of the Temple Mountain member consist of lenses several feet thick of light-gray to white sandstone and conglomeratic sandstone containing sparse to abundant carbonaceous material in the form of small stems and seams of coalified wood. Pebbles in the conglomeratic sandstone are clear to milky or pink quartz. In some places the carbonaceous material is very abundant and the rock is a gray carbonaceous siltstone or fine-grained sandstone with carbon films along bedding planes. Channels filled with the Temple Mountain member generally trend northwestward (Raymond C. Robeck, oral communication).

Nonchannel deposits of the Temple Mountain member, probably flood-plain deposits or material laid down by sheet wash over a nearly flat surface, consist largely of mudstone and siltstone with sparse fine to coarse clear subrounded quartz grains scattered throughout them. In some places these deposits are very difficult to distinguish from the underlying Moenkopi formation and may well be largely composed of reworked Moenkopi.

\section{MONITOR BUTTE MEMBER}

The Monitor Butte member of the Chinle formation reaches a maximum thickness of about 100 feet and is largely composed of purplish-red mudstone and occasional thin fine-grained sandstone and siltstone lenses having slumped bedding planes that dip as much as $45^{\circ}$ from the horizontal. From a maximum thickness in the vicinity of the Delta mine in the south end of the San Rafael Swell, the Monitor Butte thins gradually northward and pinches out near Temple Mountain and Green Vein Mesa. It is everywhere present over the southern part of the San Rafael Swell except where removed by erosion or where it is in a few places cut out by channels filled with the overlying Moss Back member.

\section{MOSS BACK MEMBER}

The Moss Back member of the Chinle formation consists of interfingering lenses of sandstone, conglomerate, and mudstone and ranges 
in thickness from 8 to about 120 feet (Raymond C. Robeck, oral communication). The sandstone and conglomerate are generally light gray to tan, and the mudstone is red or greenish gray. North of Temple Mountain and Green Vein Mesa, the Moss Back lies directly on the Temple Mountain member and is a thick massive blanketlike deposit of relatively uniform lithologic character and thickness except for large mudstone lenses in several areas. At Green Vein Mesa, about midway along the west flank of the San Rafael Swell, the Moss Back lies directly on the Moenkopi where channels have cut out the Temple Mountain member. In the southern third of the swell, the Moss Back is characterized by an abundance of channel fills that extend as much as 45 feet into the underlying Monitor Butte and have an average trend of about $\mathrm{N} .30^{\circ} \mathrm{W}$.

\section{CHURCH ROCK MEMBER}

The Church Rock member of the Chinle formation ranges in thickness from about 110 to 225 feet and is composed predominantly of red to purplish-red siltstone and fine-grained sandstone and local lenses of light-gray to medium- to coarse-grained sandstone. This unit interfingers with the underlying Moss Back.

\section{"PORPLE-WHITE" ZONE}

Over much of the San Rafael Swell there is a zone as much as 30 feet thick of mottled purple, red, pink, brown, yellow, green, and white coloring that occurs everywhere at approximately the same stratigraphic horizon (at or immediately above the top of the Moenkopi) but which in detail crosses formational contacts. This rather distinctive zone was described and called "purple-white" by Finch (1953) and is known now as the "purple-white" or the "pinto" zone. It is not confined to any particular rock type but is best developed in siltstone and fine sandstone and is least obvious in coarse grit or conglomeratic sandstone. The coloring is due to the presence of hematite and limonite and does not characteristically follow bedding planes. Where best developed, the purple, red, and brown colors of the iron-rich parts of the rock become less intense downward and occur in irregular concretion-like masses which often have a preferred orientation normal to the bedding. No foreign iron seems to have been introduced; apparently the iron that was originally distributed evenly throughout the rock was redistributed.

W. L. Stokes (written communication, 1947) says of the "purplewhite" zone in the Temple Mountain area (the unit to which Stokes refers is for the most part the Temple Mountain member of this report):

The upper portion of the Moenkopi immediately beneath the Shinarump shows evidence of extensive leaching manifested mainly by color changes, crusts and 
nodules of cherty material, and especially by what appears to be an ancient lateritic zone. The lateritic zone lies from a few to 30 feet below the contact and consists of a resistant, poorly defined bed in which irregular nodules, streaks, and segregations of iron and manganese are present, the whole being best described as mottled.

The writer concurs with Stokes' suggestion that the "purple-white" zone is something akin to an ancient lateritic zone or soil profile. Aside from its origin this zone is of interest because it is ore bearing in places and because it underlies the ore-bearing Moss Back member of the Chinle formation in the northern part of the San Rafael Swell except where it is scoured out beneath this unit. Absence of the "purple-white" zone then can sometimes be taken as evidence of channeling before or during deposition of the overlying Moss Back. Conversely, presence of the "purple-white" zone can sometimes be taken as evidence that there was little or no scouring.

\section{BLEACHING OF THE MOENKOPI FORMATION}

Over wide areas in the central, southern, and northern parts of the San Rafael Swell the Moenkopi formation is light greenish gray to yellowish brown rather than the normal red brown. In some places the boundary between gray and red parts of the Moenkopi is very abrupt and crosses bedding planes. Pyrite is common as fine grains scattered throughout the greenish-gray Moenkopi, and it seems probable that ferric iron normally present in the rock was in some way reduced and pyrite formed. Gilluly (1929, p. 86) has suggested that the reddish-brown sandstones and shales may represent terrestrial deposits oxidized during their deposition and that the greenishgray sandy shales and pyritic shales may have been deposited under conditions where strong reducing agents were present and oxidation was inhibited. Two other possibilities are that the greenish-gray colors are related to the petroleum or natural-gas content of the rock or to the action of hot springs or similar hydrothermal solutions. The general lack of abnormal radioactivity in the greenish-gray Moenkopi; the widespread occurrence of these rocks over the central parts of the San Rafael domal structure; and the presence of petroleum residues, pyrite, and gypsum in them lead the writer to believe that the greenish-gray colors are related to the reducing effects of petroleum or natural gas rather than to original conditions of deposition or to hydrothermal solutions.

\section{STRUCTURE}

The San Rafael Swell is a large asymmetrical anticline or elongate dome that trends about $\mathrm{N} .30^{\circ} \mathrm{E}$. and extends over an area about 50 to 60 miles long and 20 to 30 miles wide. The western flank of the structure has an average dip of about $5^{\circ}$, but the eastern flank has 
dips ranging from $8^{\circ}$ to $85^{\circ}$. Many small normal faults are present in the district, but only a few have a displacement greater than 100 feet. One of the largest faults in the district is reported to have a displacement of 340 feet (Gilluly, 1929). Where faults intersect ore bodies in the San Rafael district (for example, at Temple Mountain and Tomsich Mountain) the ore bodies are displaced and the faults are interpreted to be postore (Raymond C. Robeck, oral communication).

At Temple Mountain is a collapse structure and zone of fracturing and brecciation known variously as "the flopover," "the fumerole," or "the tongue." Recently several drill holes put down by the Atomic Energy Commission have shown that the zone of fracturing and brecciation extends downward into the upper part of the Coconino formation and that the Sinbad limestone member of the Moenkopi formation and the Kaibab limestone are both absent (Keys and White, 1956). Core from these holes contains pyrite, arsenopyrite, orpiment, and realgar, as well as uranium and asphalt, and is suggestive of hotsprings activity. The absence of the two limestone units here is probably due to solution either by ground water or hot ascending waters and may be in part, or wholly, responsible for the collapse of overlying beds. Several other small collapse structures, usually not more than 300 feet or so across, occur near Temple Mountain and in the north and southwest parts of the San Rafael Swell. Most of these are bleached and have an appearance suggestive of hotsprings activity.

\section{IGNEOUS ROCKS}

A number of analcite-biotite diabase sills and dikes occur in the southernmost part of the San Rafael district and are probably Tertiary in age (Gilluly, 1929, p. 120). These dikes and sills were examined for anomalous radioactivity by Pitman and Jensen (written communication, 1951) of the U. S. Atomic Energy Commission in 1951 and by U. S. Geological Survey personnel in 1955 (Raymond C. Robeck, oral communication) with negative results. The dikes are not found in or very close to ore deposits, and they are in part controlled by fractures and faults that appear to be part of the same system of fractures and faults that displace ore bodies in the southern part of the swell. For these reasons, it seems probable that the igneous dikes and sills are not genetically related to ore deposits in the San Rafael district.

\section{ORE DEPOSITS}

Uranium occurs in the San Rafael district in uranium-copper deposits (more uranium than copper), vanadium-uranium deposits 
(more vanadium than uranium), and in deposits containing uranium with only trace amounts of other metals. These deposits are for the most part in fluviatile sandstones essentially parallel to the bedding and are closely associated with carbonized wood and (or) asphaltic material. The location and size range of known deposits are shown on plate 2.

Most of the deposits in the San Rafael district are classified as uranium-copper deposits or simply as uranium deposits. Copper is commonly present in amounts less than the uranium content but in sufficient quantity so that copper minerals are fairly common in both oxidized and unoxidized deposits. On and close to the outcrop the deposits are oxidized, and limonite and yellow, orange, green, and blue secondary uranium and copper minerals call attention to the deposit. A few feet away from the outcrop the ores are largely unoxidized and the principal uranium mineral is uraninite. Pyrite, chalcopyrite, galena, and sphalerite are present in small amounts as gangue minerals.

Vanadium-uranium deposits occur mostly at Temple Mountain. The vanadium: uranium ratio here is about 3 to 1 , and the uranium ore is principally uraninite associated with carbonaceous material. Corvusite, rauvite, uvanite, carnotite, tyuyamunite, fourmarierite, abernathyite, and montroseite occur as accessory uranium- and vanadium-bearing minerals (Weeks and Thompson, 1954).

A brief study was made of the size and grade of uranium deposits in the San Rafael district and of the proportion of the district's total ore contained in each of several size ranges (fig. 13). About 92 percent of the district's ore occurs in deposits larger than 100,000 tons in size (the writer considered the Temple Mountain deposits as one big deposit containing many ore bodies joined by weakly mineralized ground). The many small deposits scattered throughout the district will probably not have a very large total production. The average grade of ore produced through calendar year 1954 from the San Rafael district is a little lower than the average grade of production from formations of Triassic age on the Colorado Plateau. The lower average grade of San Rafael ore is largely due to the low grade of shipments made from the many small prospects in the district and to the relatively low grade of the large tonnages shipped from the Temple Mountain deposits. The average ore thickness for deposits in the San Rafael district is about 1 to $1 \frac{1}{2}$ feet for small deposits and 3 to 7 feet for the large deposits. Maximum thicknesses of 20 to 30 feet are found in parts of the Delta mine. 


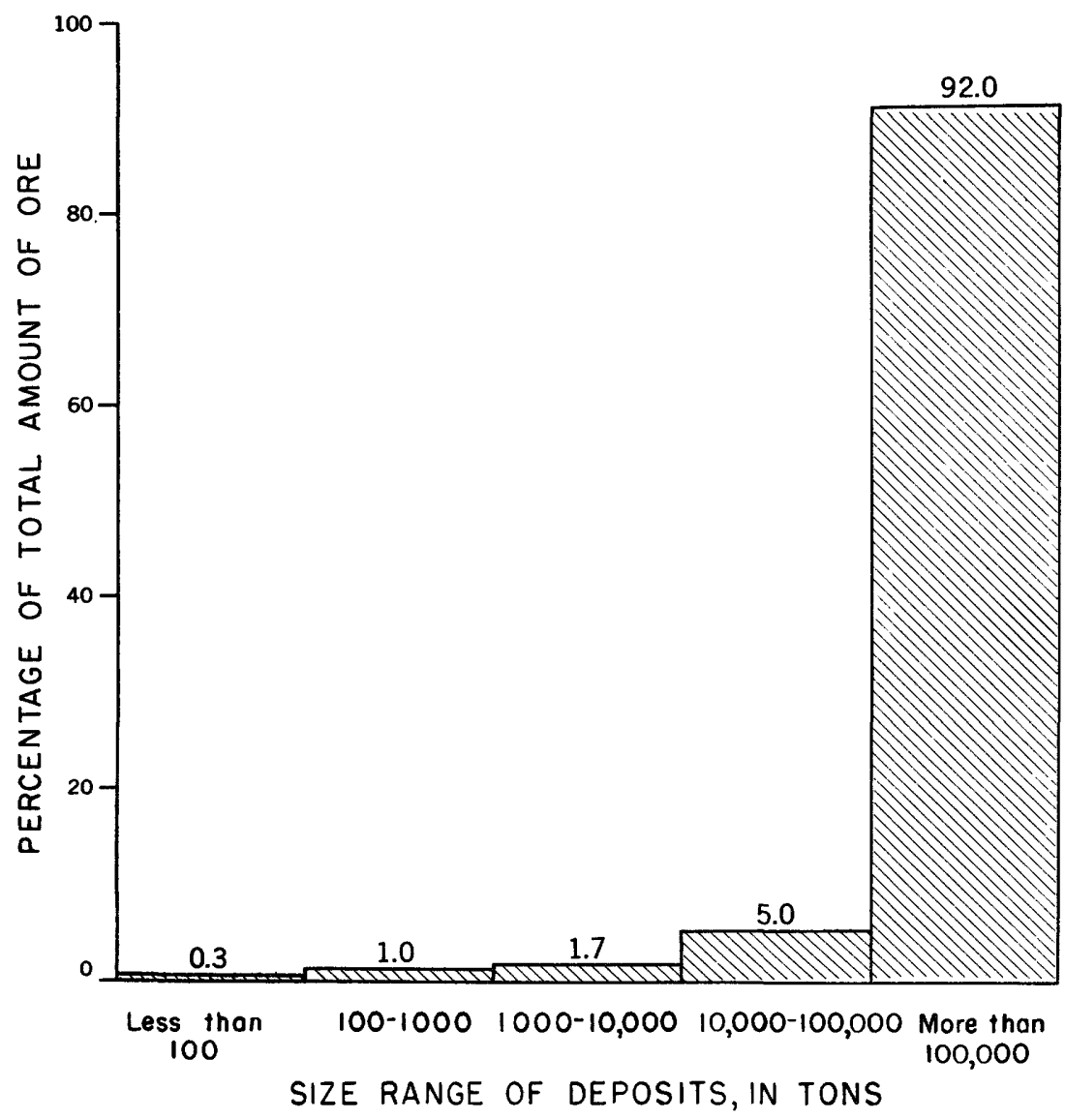

Figure 13.-Bargraph showing percentage of the total amount of ore (production through 1954 plus in dicated and inferred reserves) in the San Rafael district that is contained in deposits of various size ranges.

Uranium deposits in the San Rafael district occur at several different stratigraphic horizons but are essentially confined to the 60 -foot-thick stratigraphic interval immediately above the top of the Moenkopi formation. At the Delta mine in the south end of the San Rafael swell the ore is in a sandstone unit in the Monitor Butte member of the Chinle formation, about 20 feet above the Moenkopi. At Temple Mountain and elsewhere around the east, south, and west flanks of the swell, most of the known deposits are in the Moss Back member of the Chinle formation and may be as much as 60 feet above the Moenkopi formation. In the north end of the swell, small low-grade deposits occur at several places in conglomeratic sandstone and siltstone in the Temple Mountain member of the Chinle formation.

In the collapse structure at Temple Mountain, uranium has been found in small amounts throughout the zone of fracturing and breccia- 
tion from the Wingate sandstone down to the upper part of the Coconino. A little production has come from deposits in the Wingate at Temple Mountain, but the Moenkopi, Kaibab, and Coconino formations, although weakly mineralized in the collapse zone, are not known to contain deposits of any appreciable size. Hess (1933, p. 457) was one of the first geologists to study the Temple Mountain collapse structure and was of the opinion that the "bedded" ore deposits in the Chinle formation there were in place prior to the introduction of hot waters into the collapse zone and that the ascending hot waters redistributed some of the uranium throughout the collapse zone. The writer concurs with this opinion.

Besides the deposits in the collapse structure at Temple Mountain, several other fracture-controlled ore deposits are known in the San Rafael Swell. About 2 $\frac{1}{2}$ miles northeast of the Lucky Strike mine, uranium occurs in a fault zone in the Church Rock member of the Chinle formation. On the south end of Calf Mesa, uranium is associated with asphalt in a fault zone. At the Copper Globe mine in the western part of the San Rafael district, traces of uranium occur with malachite, azurite, and chalcocite (?) in very small "bedded" and possibly fracture-controlled deposits in the Navajo sandstone. Also, several small collapse structures in the southwest part of the swell contain weakly mineralized copper- and uranium-bearing rock (Robeck and Dyer, 1956).

Most of the ore deposits in the San Rafael district are several times as long as they are wide and occur in fluviatile sandstone lenses that are thought to be channel-fill sediments. Commonly these deposits are obviously in channels which were cut into the underlying unit. Some ore deposits are not in obvious channels, but detailed study may show that the ore-bearing unit is a channel-fill deposit at these points. Within a favorable channel structure, interfingering sandstone and mudstone facies form permeability traps which would confine or slow down ore-bearing solutions. Carbonaceous material is usually present in the ores and may have played an important part in the precipitation of ore minerals from the metal-bearing solutions. Regional facies changes or pinchouts of permeable units may also control the localization of ore to some extent. The author knows of no tectonic structural control of ore deposits in the San Rafael district except for the small deposits in the Coconino, Kaibab, Moenkopi, and Wingate formations in the collapse structure at Temple Mountain; the deposit in the Church Rock member of the Chinle formation northeast of the Lucky Strike mine; the deposit in the fault zone on Calf Mesa; and possibly the Copper Globe mine.

Approximately 450 square miles of the San Rafael district are underlain by the 60 -foot-thick ore-bearing zone. In about 14 percent of 
this area the ore-bearing zone is not more than 500 feet below the surface; about 29 percent is underlain by the ore-bearing zone at depths of 500 to 1,000 feet; and about 57 percent of the area is underlain by the ore-bearing zone at depths greater than 1,000 feet (pl. 2). Assuming no tectonic structural control of the ore deposits it can be inferred that about 43 percent of the potential reserves in the San Rafael district occur at depths less than 1,000 feet.

Several hypotheses have been suggested to explain the origin of uranium deposits such as those in the San Rafael district. At this time, the source of the metals and ore-bearing solutions is not known. Whatever the source of the metals and the solutions carrying them, the ore-bearing solutions apparently moved for the most part laterally through the rocks until a permeability trap or a favorable chemical environment caused precipitation of the ore minerals.

\section{RELATIVE FAVORABILITY OF GROUND}

All of the potentially ore-bearing ground in the San Rafael district is not equally favorable for uranium deposits. Knowledge of the geology of the district and the ore deposits, the probable controls of ore deposition, and what constitutes favorable host rocks and good passageways for the moving ore solutions enables one to attempt to predict favorable areas as opposed to areas where significant ore deposits are less likely to occur (pl. 2).

Study of the ore deposits in the San Rafael district indicates that the greater part of the potential reserves can be expected to lie somewhere in the 60-foot-thick stratigraphic interval immediately above the Moenkopi formation. Some ore may be at other horizons in zones of fracturing or brecciation associated with collapse structures or faults, but this is not expected to constitute a significant part of the potential reserves.

Ore deposits in the Temple Mountain member of the Chinle formation in the San Rafael district are small and are confined to the channel-fill type of sediments. Many Temple Mountain channels trend northwestward across the north end of the San Rafael Swell, and it would seem that these should be favorable for uranium deposits. They do not contain good ore deposits where exposed, however, and the writer feels that the sandstone lenses in these channels may be too thin and discontinuous to provide good passageways for the laterally moving ore-bearing solutions. The nonchannel facies, predominantly mudstone, of the Temple Mountain member usually overlies the sandstone lenses and may have prevented passage of solutions from the Moss Back to the permeable channel-fill lenses. Also, where the "purple-white" zone is well developed in the Temple Mountain member, hematite cement in the rock may have made it relatively 
impermeable. At best, the Temple Mountain member of the Chinle can only be considered somewhat favorable for small uranium deposits in the northern part of the San Rafael district and relatively unfavorable elsewhere in the area.

The Monitor Butte member of the Chinle formation is present beneath the Moss Back member over most of the southern third of the San Rafael Swell. The only significant ore deposit known at present in this member is the Delta mine. This deposit is in the thickest part of a sandstone lens that interfingers laterally with purplish-red mudstone of the Monitor Butte and is usually separated from the overlying Moss Back member by several feet of similar mudstone. The ore-bearing sandstone lens here cannot be traced for more than a few hundred feet along the outcrop but is evidently continuous enough and permeable enough to have allowed the free passage of the mineralizing solutions through it. Similar sandstone lenses in the Monitor Butte, if they are present, should be favorable for other large uranium deposits. However, the Monitor Butte member pinches out northward, and the Delta mine may be near the northern fringe of thick sandstone lenses in the Monitor Butte. There are at least six other prospects in sandstone lenses in the Monitor Butte in the southern part of the San Rafael Swell, but none of these lenses approaches the dimensions of the sandstone lens at the Delta mine and apparently none of these deposits is very large. However, the Monitor Butte may be generally favorable throughout the southernmost part of the district in a broad northwestward-trending belt roughly parallel to the regional pinchout of the member. If other sandstone lenses approaching the dimensions of the lens at the Delta mine are present in the Monitor Butte in this belt, some of them may contain significant uranium deposits.

The Moss Back member of the Chinle formation is present over the whole San Rafael district, except in the central portions where erosion has exposed older rocks, and is uranium bearing at many places. All the significant deposits are either in channels at the base of the Moss Back or at places where the Moss Back thickens locally. Also, the better deposits appear to be in a channel-fill sandstone that is highly crossbedded, contains carbonized logs and much coalified plant material in thin seams, and in which green mudstone lenses interfinger with the sandstone.

North of Temple Mountain and Green Vein Mesa the Moss Back is a thick, relatively massive blanket of sandstone and conglomerate. In this area the "purple-white" zone is everywhere present immediately below the Moss Back and by its presence indicates a minimum of scouring at the base of the Moss Back. The uniform thickness and lithologic character of the Moss Back and the lack of channeling at its 
base suggest that it is unfavorable for uranium depoists in the northern half of the San Rafael district.

At Temple Mountain a local thickening of the Moss Back is bounded on the northeast and southwest, at North and South Temple Washes, by Moss Back that is thinner than average. Good evidence of a channel is lacking, and there is little or no sign of scouring into the "purple-white" zone,which is well developed below the Moss Back here. However, the writer believes that the thicker Moss Back probably does represent deposition in a broad shallow channel or channel system. Cross-stratification studies in the vicinity of Temple Mountain indicate an average northwesterward flow direction for the streams that deposited the ore-bearing rocks (Stewart, 1957). The most likely extension of the favorable ground at Temple Mountain is southeastward back along the trend of the Moss Back streams. W. L. Stokes (written communication, 1947) also recognized a thick channel or channel system in the Moss Back trending northwestsoutheast through Temple Mountain.

At Flat Top Mesa, about 3 miles west of Temple Mountain (pl. 2), the Moss Back is much thicker in the northern half of the mesa than in the southern half, and the base of the unit appears to fill a channel scour at the place where the noticeable thickening occurs. This is thought to be an extension of the Temple Mountain channel or channel system and to represent its southern edge. Significant uranium deposits have been discovered by drilling within this favorable ground on the northern half of Flat Top Mesa.

At Green Vein Mesa the Moss Back fills scours cut down through the "purple-white" zone to fresh Moenkopi. The clustering of known uranium deposits, the scouring, and the presence of the channel-fill deposits in the Moss Back indicate a broad channel or channel system here. This belt of favorable ground is thought to be the northwesterly extension of the belt passing through Temple Mountain and Flat Top Mesa. Its most likely extension from Green Vein Mesa is along a trend of about N. $20^{\circ} \mathrm{W}$.

South of Temple Mountain and Green Vein Mesa the Moss Back fills scours in the underlying Monitor Butte and (or) Temple Mountain member of the Chinle at many places, and some of these scours contain medium-sized uranium deposits. Larger deposits have not yet been found here, but the ground is considered relatively favorable.

\section{SUMMARY}

Geologic reconnaissance and office study of available data pertaining to the San Rafael district indicate that about 90 percent of the potential uranium reserves of the area may be expected to be in deposits larger than 100,000 tons in size. Assuming no tectonic structural 
control of ore deposits, about 40 percent of the potential reserves may be expected at depths less than 1,000 feet.

The Temple Mountain member of the Chinle formation is considered relatively unfavorable for significant uranium deposits over most of the San Rafael district and seems at best somewhat favorable for small deposits in channels in the northern part of the swell.

The Monitor Butte member of the Chinle formation thins from a maximum thickness of about 100 feet in the vicinity of the Delta mine to a line of pinchout just south of Temple Mountain and Green Vein Mesa. It is possible that the pinching out of this unit is in some way responsible for a broad belt of relatively favorable ground covering the southern third of the San Rafael Swell. The Monitor Butte is considered relatively favorable for significant uranium deposits in this area where it may be found to contain sandstone lenses approaching the thickness (10 to 30 feet or more) of the sandstone lens at the Delta mine.

The Moss Back member of the Chinle formation is considered relatively favorable for significant deposits along the southeastward or northwestward trend of a favorable belt passing through Temple Mountain and Green Vein Mesa and in Moss Back channels in that part of the San Rafael Swell south of Temple Mountain and Green Vein Mesa.

\section{LITERATURE CITED}

Baker, A. A., 1946, Geology of the Green River Desert-Cataract Canyon region, Emery, Wayne, and Garfield Counties, Utah: U. S. Geol. Survey Bull. 951.

Emery, W. B., 1918, The Green River Desert section, Utah: Am. Jour. Sci., 4th ser., v. 46, p. 558 .

Finch, W. I., 1953, Geologic aspects of the resource appraisal of uranium deposits in pre-Morrison formations of the Colorado Plateau: U. S. Geol. Survey TEI-328A, issued by U. S. Atomic Energy Comm. Tech. Inf. Service, Oak Ridge, Tenn.

Gilluly, James, 1929, Geology and oil and gas prospects of part of the San Rafael Swell, Utah: U. S. Geol. Survey Bull. 806-C, p. 69-130.

Gilluly, James, and Reeside, J. B., Jr., 1928, Sedimentary rocks of the San Rafael Swell and some adjacent areas in eastern Utah: U. S. Geol. Survey Prof. Paper 150-D, p. 61-110.

Hess, F. L., 1922, Uranium-bearing asphaltite sediments of Utah: Eng. and Min. Jour. Press, v. 114, p. 272-276.

1933, Uranium, vanadium, radium, gold, silver, and molybdenum sedimentary deposits, in Ore deposits of the Western States (Lindgren volume): Am. Inst. Min. Metall. Engineers, p. 450 481 .

Hess, F. L., and Schaller, W. S., 1914, Pintadoite and uvanite, two new vanadium minerals from Utah: Washington Acad. Sci. Jour., v. 4, p. 576-579.

Hinckley, D. N., 1952, An investigation of subsurface isorad methods, Temple Mountain, San Rafael district, Utah: U. S. Atomic Energy Comm. RME4019, issued by U. S. Atomic Energy Comm. Tech. Inf. Service, Oak Ridge, Tenn. 
Hunt, C. B., Averitt, Paul, and Miller, R. L., 1953, Geology and geography of the Henry Mountains region, Utah: U. S. Geol. Survey Prof. Paper 228.

Keys, W. S., 1956, The Delta mine, San Rafael Swell, Emery County, Utah: U. S. Atomic Energy Comm. RME 59, issued by U. S. Atomic Energy Comm. Tech. Inf. Service, Oak Ridge, Tenn.

Keys, W. S., and White, R. L., 1956, Investigation of the Temple Mountain collapse and associated features, San Rafael Swell, Emery County, Utah, in Page, Stocking, and Smith, Contributions to the geology of uranium and thorium by the United States Geological Survey and Atomic Energy Commission for the United Nations International Conference on Peaceful Uses of Atomic Energy, Geneva, Switzerland, 1955: U. S. Geol. Survey Prof. Paper 300.

Moore, R. B., and Kithil, K. L., 1916, A preliminary report on uranium, radium, and vanadium: U. S. Bureau of Mines Bull. 70 .

Robeck, R. C., 1956, Temple Mountain member-a new member of the Chinle formation in the San Rafael Swell, Utah: Am. Assoc. Petroleum Geologists Bull., v. 40, no. 10, p. 2499-2506.

Robeck, R. C., and Dyer, H. B., 1956, San Rafael Swell area, Utah-Uranium in sandstone-type deposits, in Geologic investigations of radioactive deposits, semiannual progress report, June 1, 1955 to Nov. 30, 1955: U. S. Geol. Survey TEI-590, issued by U. S. Atomic Energy Comm. Tech. Inf. Service, Oak Ridge, Tenn., p. 49-51.

Stewart, J. H., 1957, Proposed nomenclature of part of Upper Triassic strata in southeastern Utah: Am. Assoc. Petroleum Geologists Bull., v. 41, no. 3, p. 441-465.

Weeks, A. D., and Thompson, M. E., 1954, Identification and occurrence of uranium and vanadium minerals from the Colorado Plateau: U. S. Geol. Survey Bull. 1009-B. 

